\title{
PEMATUHAN SYARIAH DALAM OPERASI TAKAFUL DI BAWAH AKTA PERKHIDMATAN KEWANGAN ISLAM (APKI) 2013
}

\section{Shariah Compliance of the Operation of Takaful under the Islamic Financial Services Act 2013}

\author{
Rusni Hasan ${ }^{1}$ \\ Safinar Salleh ${ }^{2}$
}

\begin{abstract}
The enforcement of the Islamic Financial Services Act 2013 (IFSA) brought many changes to the Islamic finance industry in Malaysia, especially in regards to Shariah compliance. The Act emphasises Shariah-compliant requirements which must be fulfilled by all Islamic financial insitutions (IFIs). The enhancement of this feature by the IFIs may increase public confidence and ensure stability in the Islamic financial system, including takaful. With regard to the latter, several improvements have been made in IFSA in respect to the insufficienies of the Takaful Act 1984 by incorporating new provisions including those related to Shariah. This article aims to examine the impact of the
\end{abstract}

\footnotetext{
Associate Professor, IIUM Institute of Islamic Banking and Finance, International Islamic University Malaysia, hrusni@iium.edu.my

2 Assistant Professor, Islamic Law Department, Ahmad Ibrahim Kulliyyah of Laws, International Islamic University Malaysia, safinar@iium.edu.my
} 
Act on Shariah compliance in the operation of takaful. This study is qualitative and uses a traditional legal research method to analyse the Shariah compliance requirements in the provisions of IFSA relating to takaful. This study found that the improvements made to the Act are essentially in compliance to the Shariah, but several issues may arise from some provisions of the Act. Thus, further research should be done to resolve these issues.

Keywords: Islamic Financial Services Act 2013, Shariah compliance, takaful

\section{PENDAHULUAN}

Penguatkuasaan Akta Perkhidmatan Kewangan Islam (APKI) pada 30 Jun 2013 memperlihatkan perubahan lanskap kerangka undang-undang yang mengawal selia sistem kewangan Islam di Malaysia terutamanya industri takaful. Akta tersebut yang memansuhkan Akta Bank Islam 1983 (ABI) dan Akta Takaful 1984 (AT) dan menyediakan kerangka pengawalseliaan aktiviti kewangan Islam oleh institusi-institusi yang berada di bawah penyeliaan Bank Negara Malaysia (BNM). APKI digubal bertujuan untuk mengadakan peruntukan bagi pengawalseliaan dan penyeliaan insitusi kewangan Islam (IKI), ${ }^{3}$ sistem pembayaran dan entiti berkaitan yang lain dan pengawasan pasaran wang Islam dan pasaran pertukaran asing Islam. Keadaan ini secara langsung menjadikan APKI sebagai akta tunggal untuk IKI yang berada di bawah penyeliaan BNM; serta mempunyai ruang lingkup pengawalseliaan yang lebih luas berbanding dengan ABI dan AT yang digubal secara khusus bagi mengawal selia institusi perbankan Islam dan pengendali takaful. Antara tujuan utama APKI adalah untuk menggalakkan kestabilan kewangan dan pematuhan Syariah ${ }^{4}$ bagi industri kewangan Islam di Malaysia sejajar dengan Seksyen 2(1) Akta Bank Negara Malaysia 2009 (ABNM) yang mendefinisikan perniagaan kewangan Islam sebagai "apa-apa perniagaan kewangan dalam ringgit atau mata wang lain yang tertakluk kepada undang-undang yang dikuatkuasakan oleh BNM dan selaras dengan Syariah".

Perkhidmatan kewangan Islam yang dibenarkan dan dikawalselia oleh APKI terbahagi kepada dua bahagian iaitu "perniagaan yang dilesenkan" dan juga "perniagaan yang diluluskan". Perniagaan yang dilesenkan oleh Menteri, atas syor BNM, merangkumi perniagaan perbankan Islam, perniagaan

3 Seksyen 2(1) Akta Bank Negara Malaysia 2009 (Akta 701) mendefinisikan institusi kewangan Islam sebagai suatu institusi kewangan Islam yang menjalankan perniagaan kewangan Islam.

4 Seksyen 6, Akta Perkhidmatan Kewangan Islam 2013. 
takaful, perniagaan perbankan Islam antarabangsa dan perniagaan takaful antarabangsa. ${ }^{5}$ Manakala perniagaan yang diluluskan oleh BNM pula adalah bentuk-bentuk perniagaan berkaitan operasi sistem pembayaran, instrumen pembayaran Islam dan pengeluaran instrumen pembayaran Islam yang ditetapkan, perniagaan pembrokeran takaful, perniagaan nasihat kewangan Islam, pasaran wang Islam dan pasaran pertukaran asing Islam. ${ }^{6}$ Artikel ini akan membahaskan peruntukan-peruntukan APKI berkaitan kehendak Syariah dan sebahagian undang-undang substantif yang terpakai dalam industri takaful sahaja.

\section{METODOLOGI KAJIAN}

Kajian ini adalah kajian ilmiah bersifat kualitatif yang bergantung kepada dua metode utama sebagai asas iaitu metode pengumpulan data dan metode penganalisaan data. Kaedah pengumpulan maklumat melalui metode penyelidikan perpustakaan digunakan bagi mendapatkan kefahaman yang jelas berkenaan peruntukan APKI berkaitan kehendak Syariah dalam operasi takaful. Kajian ini juga merujuk kepada teks-teks perundangan serta penulisan sarjana kontemporari yang didapati dalam bentuk buku, artikel, makalah dan sebagainya. Maklumat yang diperolehi melalui sumber-sumber di atas dianalisis dan diteliti menggunakan metode induktif dan deduktif. Metode induktif digunakan untuk menganalisis peruntukan-peruntukan yang berkaitan bagi mendapatkan gambaran tentang peruntukan undang-undang berkaitan kehendak Syariah ke atas pengendali takaful sebagaimana yang terdapat dalam APKI. Di samping itu, metode deduktif digunakan bagi meneliti kesesuaian penggunaan suatu teori atau konsep yang berkaitan dalam operasi takaful.

\section{PERUNTUKAN-PERUNTUKAN BERKAITAN KEHENDAK SYARIAH KE ATAS PENGENDALI TAKAFUL DI BAWAH APKI}

APKI mempunyai peruntukan yang khusus berkaitan dengan kehendak Syariah untuk dipatuhi oleh semua IKI termasuk syarikat pengendali takaful. Secara umumnya kehendak Syariah di bawah APKI terdiri daripada 3 komponen iaitu (a) Pematuhan Syariah (Seksyen 27-29); (b) Tadbir Urus Syariah (Seksyen 30-36); (c) Audit atas pematuhan Syariah (Seksyen 37-38). APKI juga menyediakan beberapa bentuk tindakan penguatkuasaan dan penalti yang boleh di ambil ke atas pihak yang tidak patuh kepada kehendak Syariah sebagaimana yang diperuntukkan dalam akta.

Seksyen 8(1)(a) dan Seksyen 10, Akta Perkhidmatan Kewangan Islam 2013.

6 Seksyen 8(1)(b) dan Seksyen 11, Akta Perkhidmatan Kewangan Islam 2013. 


\section{Pematuhan Syariah}

Pematuhan Syariah merangkumi kewajipan syarikat pengendali takaful berlesen untuk sentiasa memastikan aspek Syariah adalah dipatuhi sepenuhnya; termasuklah dari segi matlamat, pengendalian, perniagaan, hal ehwal dan aktiviti syarikat takaful tersebut. Kewajipan pematuhan aspek Syariah ini adalah merupakan kehendak yang berterusan selagi mana syarikat itu menjalankan perniagaan takaful. ${ }^{7}$ Pematuhan aspek Syariah ini termasuklah juga keperluan mematuhi apa-apa keputusan yang dibuat oleh jawatankuasa Syariah pengendali takaful terbabit serta keputusan Majlis Penasihat Syariah (MPS) $\mathrm{BNM}^{8}$ berkaitan dengan perkara-perkara tersebut. ${ }^{9}$

Sekiranya sesebuah syarikat takaful tidak mematuhi Syariah atau menyalahi nasihat jawatankuasa Syariah atau keputusan MPS BNM, tindakan-tindakan di bawah perlu dilakukan oleh institusi terbabit: ${ }^{10}$

i. Dengan serta merta memaklumkan kepada BNM dan jawatankuasa Syariah berkenaan dengan ketidakpatuhan yang berlaku;

ii. Dengan serta-merta berhenti daripada menjalankan perniagaan, hal ehwal atau aktiviti itu dan daripada mengambil apa-apa perniagaan, hal ehwal atau aktiviti lain yang serupa; dan

iii. Dalam tempoh tiga puluh (30) hari setelah menyedari ketidakpatuhan atau apa-apa tempoh yang lanjut sebagaimana yang ditentukan oleh $\mathrm{BNM}$, institusi terbabit perlu mengemukakan kepada BNM suatu rancangan mengenai pembetulan ketidakpatuhan itu.

Dalam konteks ketidakpatuhan Syariah, APKI memberikan kuasa budi bicara kepada BNM untuk menjalankan siasatan penilaian terhadap pengendali takaful yang terlibat bagi memastikan tahap ketidakpatuhan yang berlaku serta memastikan sama ada institusi terbabit telah mengambil tindakan yang sewajarnya bagi membetulkan aspek ketidakpatuhan tersebut. ${ }^{11}$ Kegagalan sesebuah syarikat takaful dalam mematuhi aspek pematuhan Syariah yang

Seksyen 28(1), Akta Perkhidmatan Kewangan Islam 2013.

8 MPS BNM yang ditubuhkan di bawah Akta Bank Negara Malaysia 2009 (Akta 701) adalah merupakan pihak berkuasa bagi penentuan hukum Syarak bagi maksud perniagaan kewangan Islam yang berada di bawah penyeliaan BNM. Aspekaspek perundangan berkaitan dengan MPS adalah dikawalselia oleh peruntukanperuntukan yang terkandung di dalam Akta 701 (Seksyen 51 hingga 58).

$9 \quad$ Seksyen 28 (2) dan (3), Akta Perkhidmatan Kewangan Islam 2013.

10 Perenggan 28 (3)(a)(b) dan (c), Akta Perkhidmatan Kewangan Islam 2013.

11 Subseksyen 28 (4), Akta Perkhidmatan Kewangan Islam 2013. 
disebutkan di atas, adalah merupakan suatu kesalahan, dan boleh, apabila disabitkan, dikenakan hukuman penjara selama tempoh tidak melebihi 8 tahun atau didenda tidak melebihi RM 25 juta atau kedua-duanya sekali. ${ }^{12}$

BNM juga diberikan kuasa untuk menentukan standard berkaitan dengan perkara Syariah berdasarkan kepada nasihat atau keputusan daripada MPS. Dalam hal ini, BNM boleh menentukan standard mengenai perkara Syariah berkenaan dengan perjalanan perniagaan, hal ehwal atau aktiviti pengendali takaful yang menghendaki penentuan hukum Syarak oleh MPS; dan untuk memberi kesan kepada nasihat atau keputusan MPS. ${ }^{13}$ Selain itu, BNM juga boleh untuk menentukan standard yang berkaitan dengan pematuhan Syariah seperti tadbir urus Syariah yang merangkumi (a) fungsi dan kewajipan lembaga pengarah, pegawai kanan dan anggota jawatankuasa Syariah sesebuah syarikat takaful; (b) kehendak layak dan sesuai atau kehilangan kelayakan seorang anggota jawatankuasa Syariah; dan (c) fungsi pematuhan Syariah dalaman. ${ }^{14}$

Standard-standard yang dikeluarkan oleh BNM berkaitan dengan aspek pematuhan Syariah sebagaimana diperuntukkan dalam subseksyen 29(1) dan (2) hendaklah sentiasa dipatuhi oleh tiap-tiap syarikat takaful, pengarahnya, ketua pegawai eksekutifnya, pegawai kanannya atau anggota jawatankuasa Syariahnya. ${ }^{15}$ Tiap-tiap institusi juga hendaklah pada setiap masa memastikan bahawa dasar dan tatacara dalamannya mengenai tadbir urus Syariah adalah selaras dengan standard yang ditentukan oleh BNM. Adalah menjadi tanggungjawab pihak-pihak yang disebutkan di atas, pada setiap masa mematuhi dasar dan tatacara dalaman yang diterima pakai oleh institusi itu untuk melaksanakan standard yang ditentukan oleh BNM dalam subseksyen 29(1) dan (2). ${ }^{16}$ Mana-mana pihak yang gagal mematuhi apa-apa standard berkaitan aspek Syariah yang dibuat oleh BNM adalah melakukan suatu kesalahan dan boleh, apabila disabitkan, dipenjarakan selama tempoh tidak melebihi lapan tahun atau didenda tidak melebihi RM 25 juta atau keduaduanya. ${ }^{17}$

12 Subseksyen 28(5), Akta Perkhidmatan Kewangan Islam 2013.

13 Subseksyen 29(1), Akta Perkhidmatan Kewangan Islam 2013.

14 Sebagai contohnya, BNM telah mengeluarkan garispanduan yang dikenali sebagai "Shariah Governance Framework for Islamic Financial Institutions (BNM/RH/ GL_012_3)" yang mula dikuatkuasakan pada 1 Januari 2011. Garispanduan ini adalah menyediakan kerangan tadbir urus Syariah yang perlu dipatuhi oleh semua institusi kewangan yang menjalankan urusniaga kewangan Islam di Malaysia.

15 Subseksyen 29(3), Akta Perkhidmatan Kewangan Islam 2013.

16 Subseksyen 29(5), Akta Perkhidmatan Kewangan Islam 2013.

17 Subseksyen 29 (6), Akta Perkhidmatan Kewangan Islam 2013. 
APKI secara keseluruhannya menyediakan ruang lingkup yang luas dalam aspek pematuhan Syariah. Antara isu dan cabaran yang mungkin timbul dalam aspek ini adalah berkaitan rujukan kepada MPS yang merupakan satusatunya autoriti yang boleh memutuskan perkara Syariah dalam konteks kewangan Islam. Perkara ini mungkin dilihat sebagai menghadkan keluasan dan kebebasan ijtihad yang boleh dilakukan oleh jawatankuasa Syariah. Walau bagaimanapun, dalam konteks penguatkuasaan, peruntukan ini adalah baik bagi penyelarasan keputusan Syariah dan seterusnya membantu pihak mahkamah dalam membuat keputusan dalam kes-kes berkaitan kewangan Islam. Keselarasan hukum juga adalah amat signifikan dalam membantu masyarakat untuk lebih memahami kewangan Islam.

Syarikat-syarikat pengendali takaful juga mungkin menghadapi cabaran dalam proses yang perlu diikuti sekiranya berlaku sebarang ketidakpatuhan Syariah. Satu persoalan yang timbul di sini ialah sama ada sesuatu perkara berkaitan ketidakpatuhan Syariah itu perlu dimaklumkan kepada pihak BNM apabila sudah pasti statusnya sebagai tidak patuh Syariah atau diragui tidak patuh Syariah? Dalam hal ini, pihak pengendali takaful perlu mempunyai polisi dalaman dan amalan pengurusan terbaik (best practice) yang efisien dan efektif bagi mengenal pasti sebarang situasi yang boleh membawa kepada ketidakpatuhan Syariah yang memerlukan mereka melaporkan kepada pihak BNM dan seterusnya memberhentikan sebarang tindakan, produk atau perniagaan tersebut secara serta merta. Pihak pengendali takaful juga perlu bertindak secara teliti dalam menentukan samada perkara tersebut betul-betul tidak patuh Syariah sebelum memberhentikan sesuatu aktiviti atau produk tersebut. Tindakan yang kurang berhati-hati boleh membawa kerugian besar kepada syarikat.

Selain itu, tempoh tiga puluh hari yang ditetapkan oleh BNM bagi membetulkan ketidakpatuhan yang berlaku mungkin dilihat agak pendek dan membebankan pihak pengendali takaful. Namun, peruntukan tersebut dilihat dapat mengelakkan risiko yang lebih besar berlaku seperti kerugian kewangan apabila pendapatan yang terhasil daripada aktiviti tersebut tidak dapat diambilkira sebagai keuntungan. Sebaliknya, pendapatan tersebut terpaksa diderma kepada badan kebajikan. Tambahan pula, sekiranya perkara tidak patuh Syariah itu tidak dihentikan secepat mungkin, ia juga akan menjejaskan reputasi syarikat pengendali takaful yang terlibat. 


\section{Tadbir Urus Syariah}

Tadbir urus Syariah, dalam konteks APKI, merangkumi perkara yang meliputi:

1. Penubuhan jawatankuasa Syariah (Seksyen 30);

2. Pelantikan anggota jawatankuasa Syariah (Seksyen 31);

3. Kewajipan jawatankuasa Syariah dan anggotanya (Seksyen 32);

4. Pemberhentian sebagai anggota jawatankuasa Syariah (Seksyen 33);

5. Notis pemberhentian sebagai anggota jawatankuasa Syariah (Seksyen 34);

6. Maklumat untuk diberikan kepada jawatankuasa Syariah (Seksyen 35); dan

7. Perlindungan bersyarat dan kewajipan kerahsiaan (Seksyen 36).

APKI menghendaki syarikat pengendali takaful untuk menubuhkan suatu jawatankuasa Syariah bagi menasihati institusi terbabit dalam memastikan bahawa perniagaannya, hal ehwalnya dan aktivitinya adalah sentiasa patuh Syariah. ${ }^{18}$ Bagi kumpulan kewangan yang mempunyai beberapa buah institusi berlesen, permohohan boleh dibuat kepada BNM untuk menubuhkan jawatankuasa Syariah tunggal dalam kumpulan kewangan terbabit. Namun, kelulusan permohonan tersebut adalah tertakluk kepada BNM sekiranya ia berpuas hati bahawa kewujudan jawatankuasa Syariah tunggal itu berupaya menjalankan fungsi mereka secara efektif untuk memastikan pematuhan Syariah oleh semua institusi berlesen dalam kumpulan kewangan terbabit. ${ }^{19}$

Berkaitan dengan pelantikan anggota jawatankuasa Syariah, APKI menetapkan bahawa seseorang yang akan dilantik, dilantik semula atau menerima pelantikan sebagai anggota jawatankuasa Syariah mestilah memenuhi syarat-syarat "kehendak layak dan sesuai" (fit and proper criteria) serta mendapat kelulusan bertulis daripada BNM. ${ }^{20}$ Seseorang anggota jawatankuasa Syariah adalah terhenti menjadi anggota jawatankuasa Syariah dalam keadaan-keadaan berikut: ${ }^{21}$

(a) Perletakan jawatan oleh anggota jawatankuasa Syariah terbabit;

\footnotetext{
18 Subseksyen 30(1), Akta Perkhidmatan Kewangan Islam 2013.

19 Subseksyen 30(2), Akta Perkhidmatan Kewangan Islam 2013.

20 Seksyen 31 dan Appendix 2: 'Fit \& Proper' Criteria (person) of the Shariah Committee, Shariah Governance Framework for Islamic Financial Institutions.

21 Subseksyen 33(1), Akta Perkhidmatan Kewangan Islam 2013.
} 
(b) Penamatan perlantikan anggota jawatankuasa Syariah terbabit oleh pihak syarikat, tertakluk kepada kelulusan bertulis daripada BNM;

(c) Anggota jawatankuasa Syariah terbabit hilang kelayakan menurut mana-mana standard berkaitan yang dikeluarkan oleh BNM; atau

(d) Anggota jawatankuasa Syariah itu tidak lagi memenuhi kehendak layak dan sesuai sebagaimana yang ditentukan oleh BNM.

Bagi situasi di atas, pemberitahuan kepada BNM perlulah dilakukan dengan serta-merta atau tidak lewat dari 14 hari daripada tempoh seseorang terbabit terhenti menjadi anggota jawatankuasa Syariah. ${ }^{22}$ Selain dari itu, BNM juga boleh memberhentikan mana-mana ahli jawatankuasa Syariah di bawah subseksyen 33(5) berdasarkan sebab-sebab di atas. Tindakan BNM ini adalah sah di sisi undang-undang walaupun tindakan itu adalah bertentangan dengan kontrak perkhidmatan atau mana-mana perjanjian yang dibuat di bawah manamana undang-undang bertulis berkaitan dengan perlantikan anggota yang diambil tindakan tersebut.

Elemen tadbir urus Syariah juga menekankan keperluan pemberian maklumat kepada jawatankuasa Syariah apabila dikehendaki. Dalam hal ini, syarikat pengendali takaful wajib memberikan apa-apa dokumen atau maklumat yang tepat, lengkap, tidak palsu atau tidak mengelirukan kepada jawatankuasa Syariah bagi membolehkan jawatankuasa tersebut menjalankan fungsinya. ${ }^{23}$ Namun begitu, adalah menjadi tanggungjawab ahli jawatankuasa Syariah untuk tidak mendedahkan apa-apa dokumen atau maklumat yang diperolehi kepada mana-mana pihak kecuali apabila (a) melakukan apa-apa laporan kepada BNM; atau (b) pemberitahuan yang berkaitan penunaian kewajipan dan pelaksanaan fungsi sebagai ahli jawatankuasa Syariah sebagaimana yang telah ditetapkan oleh undang-undang secara suci hati. ${ }^{24}$

Pemerhatian yang menarik di sini adalah, peruntukan APKI mengenai tadbir urus Syariah tidak menyediakan peruntukan secara langsung berkenaan hukuman yang dikenakan ke atas jawatankuasa Syariah, berbanding dengan peruntukan berkenaan pematuhan Syariah yang secara jelas memperuntukkan hukuman yang akan dikenakan ke atas pihak yang tidak patuh Syariah. Oleh yang demikian, kemungkinan jawatankuasa Syariah untuk dikenakan hukuman adalah sekiranya mereka melakukan tindakan tidak patuh Syariah, dan bukannya tindakan kegagalan tadbir urus Syariah. Sehinggalah pihak BNM

\footnotetext{
22 Seksyen 33(2), Akta Perkhidmatan Kewangan Islam 2013.

23 Seksyen 35(1), Akta Perkhidmatan Kewangan Islam 2013.

24 Seksyen 35(1) dan (2), Akta Perkhidmatan Kewangan Islam 2013.
} 
mengeluarkan standard yang jelas menyatakan hukuman yang dikenakan bagi sesuatu kegagalan tindakan tadbir urus Syariah, barulah jawatankuasa Syariah terdedah kepada risiko tersebut.

\section{Audit Pematuhan Syariah}

Elemen ketiga berkaitan dengan kehendak Syariah adalah melibatkan audit pematuhan Syariah. Perkara ini terkandung dalam seksyen 37 dan 38 APKI. Berdasarkan kepada peruntukan tersebut, syarikat pengendali takaful perlu melantik mana-mana orang (juruaudit) yang diluluskan oleh BNM untuk menjalankan audit pematuhan Syariah. BNM juga diberikan kuasa untuk mengarahkan sesebuah syarikat untuk melantik mana-mana orang yang diluluskan oleh BNM bagi tujuan menjalankan audit pematuhan Syariah di institusi berkenaan, dan seterusnya mengemukakan laporan mengenai audit yang telah dijalankan kepada BNM. ${ }^{25}$ Sekiranya syarikat tersebut gagal melantik juruaudit pematuhan Syariah; atau sebagai tambahan kepada juruaudit yang dilantik; atau dalam keadaan-keadaan lain yang disifatkan wajar untuk tujuan pematuhan Syariah, maka pihak BNM boleh melantik juruaudit Syariah tertentu bagi tujuan yang sama. ${ }^{26}$ Saraan dan perbelanjaan juruaudit yang dilantik adalah ditanggung oleh pihak syarikat. ${ }^{27}$

Peruntukan mengenai audit Syariah di dalam APKI dilihat mampu untuk mempertingkatkan tadbir urus dalam sesebuah syarikat pengendali takaful terutamanya berkaitan aspek Syariah. Dengan adanya audit Syariah yang efisien di setiap syarikat takaful, keseluruhan tadbir urus organisasi akan menjadi lebih baik dan seterusnya meningkatkan tahap pencapaian serta dapat menjadi asas penambahbaikan kepada insitusi itu sendiri. Walau bagaimanapun, apa yang lebih penting adalah, bukan setakat urus tadbir organisasi sahaja yang perlu menepati kehendak Syariah, akan tetapi tenaga kerjanya juga perlu mempunyai sikap dan tingkah laku yang selaras dengan kehendak syarak.

\section{Kemungkiran-Kemungkiran Berkaitan dengan Kehendak Syariah}

APKI turut menjelaskan bentuk-bentuk hukuman yang boleh dikenakan kepada pihak-pihak yang melakukan kemungkiran terhadap peruntukanperuntukan berkaitan dengan kehendak Syariah. Seseorang adalah melakukan

\footnotetext{
25 Seksyen 37 (1) dan (2), Akta Perkhidmatan Kewangan Islam 2013.

26 Seksyen 38(1), Akta Perkhidmatan Kewangan Islam 2013.

27 Seksyen 37(3), Akta Perkhidmatan Kewangan Islam 2013.
} 
kemungkiran di bawah APKI sekiranya orang itu gagal untuk mematuhi atau memberi kesan kepada mana-mana peruntukan, peraturan, atau perintah yang di buat di bawah APKI dan akan dikenakan hukuman sebagaimana yang disebutkan di atas. ${ }^{28}$ Dalam memutuskan sesuatu tindakan yang akan diambil terhadap pihak-pihak yang mungkir, APKI menetapkan bahawa BNM hendaklah mengambil kira faktor-faktor berikut: ${ }^{29}$

(a) Keberkesanan tindakan penguatkuasaan yang akan diambil di bawah di APKI;

(b) Perkadaran tindakan yang akan diambil dengan kemungkiran yang dilakukan;

(c) Pencegahan kemungkiran masa hadapan yang serupa keadaannya oleh orang lain; dan

(d) Apa-apa perkara lain yang dipertimbangkan sebagai berkaitan pada pendapat BNM.

APKI memberikan kuasa kepada BNM untuk mengambil tindakan yang sewajarnya bagi mana-mana pihak yang telah melakukan kemungkiran terhadap peruntukan APKI. Tindakan yang boleh dilakukan oleh BNM adalah dalam bentuk:

(a) Melakukan penyiasatan ke atas mana-mana pihak yang dipercayai telah melakukan kesalahan di bawah akta ini;

(b) Mengambil tindakan pentadbiran dengan membuatkan perintah secara bertulis bagi tujuan pematuhan; mengenakan penalti monetari; membuat kenyataan umum secara bertulis mengenai pihak yang mungkir; membuat perintah secara bertulis menghendaki orang yang mungkir untuk mengambil sesuatu tindakan; serta membuat perintah untuk remedi atau restitusi kepada pihak yang terbabit dalam kemungkiran.

(c) Mengambil tindakan sivil di mahkamah untuk menuntut pampasan, perintah interim dan tindakan lain yang wajar.

Selain daripada tindakan di atas, APKI juga memperuntukkan penalti dalam bentuk kesalahan jenayah dalam bentuk penalti pemenjaraan bagi pihakpihak yang mungkir. Dalam keadaan yang sedemikian, prosedur berkenaan kesalahan jenayah perlulah diikuti.

28 Seksyen 245(1), Akta Perkhidmatan Kewangan Islam 2013.

29 Seksyen 245(2), Akta Perkhidmatan Kewangan Islam 2013. 
Pematuhan Syariah dalam Operasi Takaful di Bawah

Akta Perkhidmatan Kewangan Islam (APKI) 2013

\section{PEMBAHARUAN UNDANG-UNDANG SUBSTANTIF TAKAFUL DAN KESAN-KESANNYA DARI ASPEK SYARIAH}

Selain aspek kehendak Syariah, penguatkuasaan APKI juga telah membawa perubahan yang agak ketara kepada undang-undang takaful di Malaysia. Undang-undang takaful di bawah APKI boleh dikatakan lebih menyeluruh berbanding dengan AT. ${ }^{30}$ Penambahbaikan undang-undang takaful di bawah APKI meliputi pentafsiran yang lebih jelas bagi terma-terma berkaitan takaful, pemantapan peraturan kawal selia perniagaan takaful seperti pelesenan, pematuhan Syariah serta urus tadbir Syariah dan juga penambahan undangundang substantif takaful. Beberapa peruntukan baru yang telah ditambah dalam akta ini; antaranya ialah penyelenggaraan kumpulan wang takaful dan kumpulan wang pemegang saham, kepentingan boleh lindung takaful (permisible takaful interest), kewajipan pendedahan dan representasi pra kontrak serta penamaan dan pembayaran manfaat takaful kepada benefisiari di bawah konsep hibah bersyarat.

\section{Tafsiran Terma Takaful dan Perniagaan Takaful}

APKI telah mengemukakan definisi yang lebih jelas bagi terma-terma berkaitan takaful. Takaful ditafsirkan sebagai "suatu perkiraan yang berasaskan pertolongan secara bersama yang di bawahnya peserta takaful bersetuju untuk menyumbang kepada suatu kumpulan wang yang sama yang menyediakan manfaat kewangan bersama yang kena dibayar kepada peserta takaful itu atau kepada benefisiarinya pada masa berlaku sesuatu kejadian yang telah dipersetujui terdahulu." "31 Perniagaan takaful pula ditafsirkan sebagai "perniagaan yang berhubung dengan pentadbiran, pengurusan dan operasi kumpulan wang takaful untuk peserta takafulnya yang mungkin melibatkan elemen pelaburan dan simpanan..."32

Dalam akta ini, terma "takaful" dibezakan daripada terma "perniagaan takaful". Terma pertama merujuk kepada suatu bentuk kerjasama sesama peserta takaful (bukan dengan tujuan komersil) untuk menyediakan tabungan bagi mewujudkan manfaat kewangan bersama jika berlaku sesuatu kejadian di masa hadapan. Definisi takaful yang baru ini nampak lebih menepati konsep insuran Islam yang berasaskan konsep pertolongan secara bersama ( $\mathrm{ta}$ ' $\bar{a} w u n$ )

30 Mohamed Hadi Abd Hamid \& Rusni Hassan, 'Akta Perkhidmatan Kewangan Islam 2013: Tinjauan Awal Kesannya dalam Industri Takaful,' KANUN (2014): 256.

31 Seksyen 2(1), Akta Perkhidmatan Kewangan Islam 2013.

32 Seksyen 2(1), Akta Perkhidmatan Kewangan Islam 2013. 
dalam kalangan para peserta takaful. Sebaliknya, terma kedua pula dirujuk kepada aktiviti pengendalian operasi takaful yang dijalankan oleh syarikat takaful atas dasar komersil. ${ }^{33}$ APKI juga memberikan tafsiran yang jelas bagi perniagaan takaful dengan menyenaraikan aktiviti-aktiviti yang termasuk di bawah perniagaan tersebut seperti menerima dan merunding cadangan untuk menyertai perkiraan takaful, mengeluarkan sijil takaful, memungut atau menerima sumbangan takaful daripada para peserta dan menyelesaikan atau mendapatkan kembali tuntutan takaful (claim). ${ }^{34}$

\section{Penyelenggaraan Dana Takaful dan Dana Pemegang Saham}

Peruntukan-peruntukan berkaitan penyelenggaraan dan pengurusan dana takaful dan dana pemegang saham dalam APKI juga dilihat menepati konsep takaful. Pertama, APKI mewajibkan pengendali takaful mengasingkan dana peserta takaful daripada dana pemegang saham. ${ }^{35}$ Kedua, selaras dengan konsep takaful yang meletakkan para peserta sebagai pemilik dana takaful, APKI dilihat seolah-olah memberikan pengiktirafan terhadap pemilikan tersebut. Seksyen 92 menyatakan secara jelas bahawa pengendali takaful berperanan menyelenggara dan mengurus dana takaful bagi pihak dan bagi kepentingan terbaik para peserta. Ketiga, seksyen tersebut juga turut menjelaskan bahawa kedudukan dan peranan pengendali takaful hanyalah sebagai pengurus dana takaful. Seterusnya, peranan pengendali takaful juga dibezakan daripada syarikat insuran konvensional melalui Seksyen 96 yang meletakkan tanggungjawab pengambilalihan risiko ke atas dana takaful dan bukannya ke atas pengendali takaful. Peruntukan ini adalah selaras dengan tafsiran takaful yang telah dinyatakan di atas, yang meletakkan tanggungjawab menyediakan manfaat kewangan ke atas dana takaful.

Sekiranya berlaku kekurangan pada nilai aset dana takaful, Seksyen 95 mewajibkan pengendali takaful untuk menyediakan qard (pinjaman) atau sokongan kewangan dalam bentuk lain kepada dana takaful. Dari perspektif Syariah, qard adalah salah satu kontrak yang bersifat sukarela (tabarru') di mana seseorang meminjamkan sejumlah wang kepada pihak lain yang bertanggungjawab untuk membayar balik pinjaman tersebut pada satu masa

33 Safinar Salleh, Uzaimah Ibrahim \& Mahdi Zahraa, 'The Future of Takaful (Islamic Insurance) Business in Malaysia under the Islamic Financial Services Act (IFSA) 2013', Australian Journal of Basic and Applied Sciences (AJBAS), 8/15 (2014): 392.

34 Seksyen 5(4)(a), Akta Perkhidmatan Kewangan Islam 2013.

35 Seksyen 91, Akta Perkhidmatan Kewangan Islam 2013. 
yang tertentu. ${ }^{36}$ Pihak peminjam wajib membayar balik jumlah hutang yang dipinjam dan pihak pemberi pinjam pula tidak boleh mengenakan apa-apa faedah ke atas pinjaman tersebut kerana faedah tersebut dikira sebagai riba. ${ }^{37}$ Dalam operasi takaful, kontrak qard ini digunakan oleh pengendali takaful untuk memberikan pinjaman kewangan dari dana pemegang saham kepada dana takaful yang mengalami defisit.

Secara umumnya, penggunaan kontrak qard adalah harus. Tetapi, Seksyen 95 ini mungkin dilihat agak tidak menepati semangat kontrak qard yang bersifat sukarela, kerana ia menjadikan qard satu tanggungjawab atau liabiliti yang mana sekiranya tidak dipenuhi akan membawa kesan perundangan yang serius. Di samping itu, peruntukan ini juga dilihat tidak konsisten dengan prinsip takaful kerana ia meletakkan liabiliti kewangan tersebut ke atas pemegang saham syarikat takaful sedangkan dalam konsep takaful para peserta yang bertanggungjawab menyediakan tabungan untuk manfaat bersama secara tolong-menolong ( $t a{ }^{\prime}$ âwun). Walaupun pinjaman yang diberikan oleh dana pemegang saham itu akan dibayar balik melalui lebihan (surplus) dana takaful di masa akan datang, namun ada kemungkinan pinjaman ini terpaksa dilupus kira jika tiada lebihan dalam dana takaful dalam tempoh masa tertentu. ${ }^{38}$ Jika ini berlaku, tanggungjawab kewangan pengendali takaful dari sudut ini adalah sama dengan syarikat insuran konvensional walaupun peranan mereka adalah berbeza menurut Syariah. Perlu difahami bahawa peranan syarikat pengendali takaful hanyalah sebagai pengurus dana takaful yang disumbangkan oleh para peserta dan bukanlah sebagai 'insurer' seperti syarikat insuran konvensional. Justeru, adalah menjadi satu cabaran kepada pihak-pihak yang terlibat dalam industri takaful untuk meneroka dan mencari sokongan kewangan dalam bentuk lain seperti wakaf bagi menggantikan qard daripada dana pemegang saham untuk menampung defisit dana takaful agar lebih menepati prinsip takaful itu sendiri.

\section{Kepentingan Boleh Lindung Takaful}

Satu lagi aspek undang-undang substatif yang telah dimasukkan di dalam APKI ialah berkaitan kewajipan kepentingan boleh lindung takaful. Akta baru ini mewajibkan para peserta yang membuat kontrak takaful keluarga terhadap

36 Perenggan 8.1, Dokumen Polisi Qard yang dikeluarkan oleh Bank Negara Malaysia BNM/RH/PD 028-7; ISRA, ISRA Compendium for Islamic Financial Terms: Arabic - English (Kuala Lumpur: ISRA, 2010), 144-145.

37 Wahbah al-Zuhaylī, Al-Fiqh Al-Islāmī wa Adillatuh, vol. 4, ed. ke 3 (Damsyik: Dār al-Fikr, 1989), 724.

38 Para 14.4, Guidelines on Takaful Operational Framework, BNM/RH/GL 004-22, $27-28$. 
seorang yang dilindungi selain peserta itu sendiri, mestilah mempunyai suatu kepentingan boleh lindung dalam orang yang dilindungi pada masa kontrak takaful itu dibuat dan pada ketika manfaat takaful dibayar. ${ }^{39}$ Mana-mana peserta takaful yang membuat suatu kontrak takaful keluarga bagi melindungi orang lain dan peserta itu tidak mempunyai kepentingan boleh lindung takaful dalam orang yang dilindungi pada masa kontrak takaful itu dibuat, maka kontrak itu adalah tidak sah. ${ }^{40}$ Sekiranya kepentingan boleh lindung takaful itu luput pada bila-bila masa selepas kontrak itu dibuat, maka pengendali takaful hendaklah membayar apa-apa wang yang perlu dibayar kepada peserta takaful dan menamatkan kontrak takaful tersebut. ${ }^{41}$ Seseorang peserta takaful disifatkan sebagai mempunyai kepentingan boleh lindung takaful dalam orang yang dilindungi sekiranya orang itu adalah (a) suaminya atau isterinya atau anaknya; (b) anak jagaannya di bawah umur dewasa semasa orang itu membuat kontrak takaful tersebut; (c) pekerjanya; atau (d) seseorang yang kepadanya dia bergantung sepenuhnya atau sebahagiannya bagi saraan atau pendidikan pada masa dia membuat kontrak takaful itu. ${ }^{42}$

Walaupun APKI tidak mendefinisikan terma kepentingan boleh lindung takaful ini, maksud terma ini bolehlah difahami melalui peruntukanperuntukan berkaitan dalam Jadual 8. Secara umumnya, kepentingan boleh lindung takaful bermaksud hubungan yang wujud di antara peserta takaful dengan orang yang dilindungi, sama ada disebabkan perkahwinan, keturunan, pekerjaan ataupun saraan, yang menyebabkan jangkaan kerugian dari segi material atau psikologi ke atas peserta takaful disebabkan kematian orang yang dilindungi. Kebiasaannya, seseorang isteri akan mengalami kerugian kewangan atau psikologi apabila suaminya meninggal dunia. Begitu juga seorang majikan mungkin mengalami kerugian kewangan disebabkan kematian pekerja mahirnya. Kewajipan kepentingan boleh lindung takaful ini adalah sama seperti kewajipan kepentingan boleh insuran (insurable interest) dalam Akta Perkhidmatan Kewangan (APK) 2013. ${ }^{43}$ Konsep kepentingan boleh insuran telah diguna pakai dalam undang-undang insuran kovensional untuk mengelakkan perjudian dan pertaruhan melalui polisi insuran. Walaupun kepentingan boleh lindung ini berasal daripada undang-undang Inggeris, ${ }^{44}$ MPS BNM memutuskan bahawa ia tidaklah bertentangan dengan prinsip Syariah dan membenarkan penggunaannya dalam kontrak takaful keluarga

\footnotetext{
39 Perenggan 3(2), Jadual 8, Akta Perkhidmatan Kewangan Islam 2013.

40 Perenggan 3(3), Jadual 8, Akta Perkhidmatan Kewangan Islam 2013.

41 Perenggan 3(4)(a) dan (b), Jadual 8, Akta Perkhidmatan Kewangan Islam 2013.

42 Perenggan 3(6), Jadual 8, Akta Perkhidmatan Kewangan Islam 2013.

43 Perenggan 3(1) dan (3), Jadual 8, Akta Perkhidmatan Kewangan 2013.

44 S. Santhana Dass, Law of Life Insurance in Malaysia (Kuala Lumpur: Alpha Sigma Sdn Bhd, 2000), 67.
} 
berdasarkan prinsip sadd al zarā' $i$ ' (menutup ruang ke arah kemudaratan). ${ }^{45}$ Pemakaian peraturan kepentingan boleh lindung ini terhadap kontrak takaful keluarga adalah sangat penting untuk mengelakkan penyalahgunaan kontrak takaful keluarga untuk tujuan manipulasi dan mencegah risiko moral.

\section{Kewajipan Penuh Percaya Mutlak (Utmost Good Faith) dalam Kontrak Takaful}

Satu lagi peruntukan penting yang dimasukkan dalam APKI bagi mengelakkan manipulasi dan mencegah risiko moral, ialah kewajipan penuh percaya mutlak ke atas peserta dan pengendali takaful. ${ }^{46}$ Para peserta takaful diwajibkan untuk melakukan pendedahan dan representasi pra kontrak kepada pengendali takaful. Dalam hal ini, APKI membahagikan kontrak takaful kepada dua jenis iaitu kontrak takaful pengguna dan kontrak takaful selain kontrak takaful pengguna. ${ }^{47}$ Bentuk pendedahan pra kontrak bagi kedua-dua jenis kontrak takaful ini adalah berbeza. Pihak pencadang bagi kontrak takaful selain kontrak takaful pengguna dituntut agar mendedahkan maklumat yang diketahuinya ataupun dijangka dia ketahui akan mempengaruhi keputusan pengendali takaful sama ada untuk menerima atau tidak risiko yang dibawanya. ${ }^{48}$ Manakala bagi kontrak takaful pengguna pula, pengguna diwajibkan untuk menjawab soalan-soalan yang dikemukakan oleh pihak pengendali takaful yang boleh mempengaruhi keputusan pengendali takaful sama ada untuk menerima atau tidak risiko serta kadar dan terma yang hendak dipakai. ${ }^{49}$ Sebelum kontrak takaful keluarga diperbaharui, pengendali takaful juga boleh memberikan satu salinan maklumat yang telah didedahkan sebelum ini oleh pengguna dan memintanya mengesahkan atau meminda apa-apa perubahan pada maklumat tersebut. ${ }^{50}$ Dalam hal ini, pengguna wajib mengambil penjagaan munasabah agar tidak membuat pernyataan yang salah kepada pengendali takaful semasa menjawab soalan-soalan yang dikemukakan atau mengesahkan atau meminda maklumat sedia ada. ${ }^{51}$ Di samping itu, pengguna juga hendaklah mengambil penjagaan munasabah untuk mendedahkan kepada pengendali takaful apa-apa perkara, selain daripada soalan spesifik yang dikemukakan oleh pengendali

45 Bank Negara Malaysia, Resolusi Syariah dalam Kewangan Islam, ed. ke-2 (Kuala Lumpur: Bank Negara Malaysia, 2010), 91-93.

46 Perenggan 5(9), Jadual 9, Akta Perkhidmatan Kewangan Islam 2013.

47 Perenggan 2, Jadual 9, Akta Perkhidmatan Kewangan Islam 2013.

48 Perenggan 4(1), Jadual 9, Akta Perkhidmatan Kewangan Islam 2013.

49 Perenggan 5(1), Jadual 9, Akta Perkhidmatan Kewangan Islam 2013.

50 Perenggan 5(3)(b), Jadual 9, Akta Perkhidmatan Kewangan Islam 2013.

51 Perenggan 5(2) dan (4), Jadual 9, Akta Perkhidmatan Kewangan Islam 2013. 
takaful atau salinan maklumat terdahulu yang diberikan, jika pengguna itu tahu bahawa perkara tersebut boleh mempengaruhi keputusan pengendali takaful untuk menerima atau tidak risiko dan kadar serta terma yang hendak dipakai. ${ }^{52}$ Kegagalan memenuhi kewajipan ini boleh memberikan kesan ke atas kontrak takaful keluarga dan mungkin akan menjejaskan hak peserta takaful untuk mendapatkan tuntutan manfaat takaful. ${ }^{53}$

Peruntukan berkaitan kewajipan pendedahan dan representasi ke atas pihak peserta takaful ini adalah selaras dengan kewajipan bercakap benar yang dianjurkan dalam Islam. Dari perspektif Syariah, penipuan, kesilapan ketika memberikan maklumat atau menyembunyikan maklumat sebenar boleh menjejaskan keabsahan sesuatu kontrak terutamanya jika ianya menyebabkan kerugian kepada salah satu pihak yang berkontrak. Pihak yang terjejas dengan penipuan, kesilapan atau penyembunyian maklumat sebenar berhak membatalkan kontrak tersebut. ${ }^{54}$ Dalam kontrak takaful, tahap kepercayaan yang diperlukan daripada peserta takaful adalah lebih tinggi daripada kontrakkontrak lain kerana ianya melibatkan risiko yang akan dikongsi bersama oleh peserta-peserta yang lain. Oleh itu, peruntukan undang-undang berkaitan kewajipan pendedahan dan representasi yang diperkenalkan di dalam APKI diharapkan dapat memelihara kepentingan bersama para peserta takaful apabila ianya dikuatkuasakan nanti.

\section{Penamaan Benefisiari di bawah Hibah Bersyarat}

Satu perubahan yang paling ketara dalam undang-undang takaful yang baru ini ialah berkenaan kuasa membuat penamaan. APKI memberikan hak perundangan (statutory right) kepada peserta takaful, yang berusia 16 tahun dan ke atas, yang mengambil takaful keluarga atau takaful kemalangan diri atas hayat dirinya, untuk menamakan individu yang akan menerima manfaat takaful, yang akan dibayar atas kematiannya, sebagai benefisiari di bawah hibah bersyarat atau sebagai wași sahaja. ${ }^{55}$ Individu yang dinamakan sebagai benefisiari akan menerima manfaat takaful yang dibayar atas kematian peserta sebagai miliknya sendiri kerana manfaat takaful tersebut telah dipindah milik kepadanya melalui hibah bersyarat. Dalam situasi ini, manfaat takaful tersebut tidak menjadi harta pusaka peserta yang meninggal dunia dan tidak tertakluk

\footnotetext{
52 Perenggan 5(8), Jadual 9, Akta Perkhidmatan Kewangan Islam 2013.

53 Perenggan 13 hingga 17, Jadual 9, Akta Perkhidmatan Kewangan Islam 2013.

54 al-Zuhaylī, al-Fiqh al-Islāmī wa Adillatuh, 216-223.

55 Perenggan 2(1), Jadual 10, Akta Perkhidmatan Kewangan Islam 2013.
} 
kepada hutangnya. ${ }^{56}$ Sebaliknya, individu yang yang menerima manfaat takaful sebagai wași hendaklah membahagikan manfaat takaful tersebut mengikut wasiat peserta yang meninggal dunia ataupun mengikut undangundang berhubung pembahagian harta pusaka yang terpakai bagi pentadbiran harta pusaka peserta tersebut. ${ }^{57}$ Suatu penamaan itu akan terbatal jika penama meninggal dunia ketika peserta masih hidup, peserta membatalkan penamaan tersebut melalui notis bertulis yang dikemukakan kepada kepada pengendali takaful atau peserta membuat penamaan yang baru. ${ }^{58}$

Peruntukan undang-undang berkaitan hak peserta membuat penamaan benefisiari di bawah hibah bersyarat ini dapat memberi ruang kepada peserta untuk memastikan bahawa manfaat takaful yang akan dibayar atas kematiannya nanti akan diperolehi sepenuhnya oleh penerima hibah tersebut. Hak ini boleh dimanfaatkan untuk memelihara kepentingan keluarga terdekat peserta takaful seperti pasangan suami isteri, anak-anak atau ibu bapanya. Namun demikian, peruntukan ini telah menimbulkan beberapa isu walaupun penggunaan konsep hibah bersyarat ini telah diluluskan oleh MPS BNM. ${ }^{59}$ Pertama, kesesuaian penggunaan konsep hibah bersyarat dalam proses penamaan dalam kontrak takaful keluarga ini telah dipersoalkan kerana ia dilihat bercanggah dengan undang-undang wasiat dan pusaka Islam. $^{60}$ Dalam pelaksanaan konsep hibah bersyarat ini, manfaat takaful akan diserahkan kepada penama jika peserta takaful meninggal dunia sebelum tarikh matang suatu sijil takaful. Sebaliknya, jika peserta itu hidup hingga ke tempoh matang, manfaat takaful akan dikembalikan kepadanya. Konsep hibah bersyarat seperti ini adalah mirip kepada hibah ruqbā yang telah dibincangkan oleh para sarjana feqah. Dalam hibah ruqbā, seorang pemberi bersetuju memberikan hartanya kepada penerima jika pemberi itu meninggal dunia. Sebaliknya jika penerima yang meninggal terlebih dahulu, harta itu hendaklah dikembalikan semula kepada pemberi. ${ }^{61}$ Menurut jumhur ulama' fiqh, dalam hal ini pemilikan sesuatu hibah

56 Perenggan 3 (1) dan (2), Jadual 10, Akta Perkhidmatan Kewangan Islam 2013.

57 Perenggan 6 (2), Jadual 10, Akta Perkhidmatan Kewangan Islam 2013.

58 Perenggan 4 (1)(a)(b)(c), Jadual 10, Akta Perkhidmatan Kewangan Islam 2013.

59 Keputusan Mesyarat Majis Penasihat Syariah Bank Negara Malaysia kali ke 34 pada 21 April 2003. Peruntukan yang sama mengenai hibah bersyarat di dalam takaful juga boleh didapati di dalam Perenggan 15, Dokumen Polisi Hibah yang dikeluarkan oleh Bank Negara Malaysia BNM/RH/PD 028-5.

60 Yusuf Sani Abubakar, Muhammad Anowar Zahid and Ruzian Markom, 'Effect of Nomination under Life Insurance and Family Takaful,' ISRA International Journal of Islamic Finance, 6/1 (2014): 72-83.

61 'Abd Allāh bin Aḥmad Ibn Qudāmah, al-Mughnī, vol. 7, $3^{\text {rd }}$ ed. (Riyāụ: Dār 'Ālam al-Kutub, 1997), 282. 
itu akan berpindah terus kepada penerima dan tidak akan kembali semula kepada pemberi jika penerima itu mati semasa pemberi masih hidup. ${ }^{62}$ Walau bagaimanapun, minoriti ulama' fiqh berpendapat bahawa syarat yang dibuat dalam hibah tersebut adalah sah dan harta yang dihibah secara bersyarat itu hanya akan menjadi milik penerima jika pemberi meninggal dunia dan dikembalikan kepada pemberi jika penerima meninggal terlebih dahulu. ${ }^{63}$ Persoalannya, dalam konteks hibah bersyarat dalam amalan takaful, kenapa pihak MPS BNM mengutamakan pendapat minoriti berbanding pandangan majoriti?

Kedua, kontrak hibah bersyarat ini mungkin boleh disalahguna oleh para peserta untuk menafikan hak waris tertentu daripada menerima manfaat takaful kerana APKI tidak menyatakan dengan jelas siapakah individu yang layak dinamakan sebagai benefisiari di bawah hibah bersyarat ini. Oleh kerana akta ini juga tidak mentafsirkan maksud benefisiari dan tidak ada pula peruntukan undang-undang yang mewajibkan benefisiari mempunyai kepentingan boleh lindung takaful ke atas orang yang dilindungi (peserta takaful), akta ini memberi kuasa mutlak kepada peserta takaful untuk menamakan mana-mana individu sebagai benefisiari di bawah hibah bersyarat. Keadaan ini berbeza dengan undang-undang insuran konvensional di bawah APK yang hanya menghadkan individu-individu tertentu sahaja, iaitu pasangan suami isteri, anak atau ibu bapa (jika tiada pasangan atau anak), yang berhak menerima wang polisi atas dasar 'statutory trust' manakala penama selain daripada itu menerima wang polisi sebagai wași sahaja. ${ }^{64}$ Perbezaan hukum antara manfaat takaful dengan wang polisi insuran boleh menimbulkan kekeliruan dalam kalangan masyarakat.

\section{KESIMPULAN}

Kesimpulannya, APKI telah menambah baik peraturan berkaitan pematuhan Syariah dalam perlaksanaan sistem kewangan Islam di Malaysia. Akta ini telah mewujudkan peruntukan-peruntukan yang lebih jelas berkaitan kewajipan pematuhan Syariah oleh IKI dan meletakkan bebanan pematuhan Syariah

62 Wahbah al-Zuhaylī, Financial Transactions in Islamic Jurisprudence [al-Fiqh alIslāmī wa Adillatuh], vol. 1, trans. Mahmoud A. El-Gamal, $2^{\text {nd }}$ ed. (Damascus: Dār al-Fikr, 2007), 542-543; Muhammad Najīb al-Muțī's̄, al-Majmū' Sharh alMuhazzab, vol. 16 (Jeddah: Maktabah al-Irshād, t.t.), 363-367.

63 al-Ḥațāāb Al-Ru'ayn̄̄, Mawāhib al-Jalīl li Sharh Mukhtașar Khalīl, vol. 8 (Riyāḍ: Dār ' $\bar{A}$ lam Al-Kutub, n.d.), 22; 'Abd Allāh bin Aḥmad Ibn Qudāmah, al-Mughnī, vol. 8, 285.

64 Perenggan 5 (1)(a)(b) and 6(1), Jadual ke 10, Akta Perkhidmatan Kewangan 2013. 
Pematuhan Syariah dalam Operasi Takaful di Bawah Akta Perkhidmatan Kewangan Islam (APKI) 2013

setara dengan kewajipan memastikan kestabilan kewangan IKI. Undangundang takaful juga telah diperkemaskan dan dilihat lebih menepati kehendak Syariah. Walau bagaimanapun, beberapa kajian lanjut dari sudut Syariah perlu dilakukan dalam beberapa aspek seperti perincian ciri-ciri kepentingan boleh lindung takaful, bentuk-bentuk sokongan kewangan selain qard kepada dana takaful untuk mengatasi masalah defisit dan pelaksanaan hibah bersyarat dalam pembayaran manfaat takaful.

\section{RUJUKAN}

'Abd Allāh bin Aḥmad Ibn Qudāmah, al-Mughnī, vol. 7, $3^{\text {rd }}$ ed. (Riyāẹ: Dār 'Alam al-Kutub, 1997).

Bank Negara Malaysia, Resolusi Syariah dalam Kewangan Islam, ed. ke-2 (Kuala Lumpur: Bank Negara Malaysia, 2010).

Al-Ḥattāb al-Ru'aynī, Mawāhib al-Jalīl li Sharh Mukhtaṣar Khalīl, vol. 8 (Riyāḍ: Dār 'Alam al-Kutub, n.d.).

ISRA, ISRA Compendium for Islamic Financial Terms: Arabic - English (Kuala Lumpur: ISRA, 2010).

Mohamed Hadi Abd Hamid \& Rusni Hassan, 'Akta Perkhidmatan Kewangan Islam 2013: Tinjauan Awal Kesannya dalam Industri Takaful,' KANUN, (2014).

Muḥammad Najīb al-Mutī‘'̄, al-Majmū' Sharh al-Muhazzab, vol. 16 (Jeddah: Maktabah al-Irshād, t.t.).

S. Santhana Dass, Law of Life Insurance in Malaysia (Kuala Lumpur: Alpha Sigma Sdn. Bhd., 2000).

Safinar Salleh, Uzaimah Ibrahim \& Mahdi Zahraa, 'The Future of Takaful (Islamic Insurance) Business in Malaysia under the Islamic Financial Services Act (IFSA) 2013,'Australian Journal of Basic and Applied Sciences (AJBAS), 8/15 (2014), http://www.ajbasweb.com/old/ajbas September_2014.html, 21 April 2016.

Wahbah al-Zuhaylī, Financial Transactions in Islamic Jurisprudence [Al-Fiqh al-Islāmī wa Adillatuh], vol. 1, trans. Mahmoud A. El-Gamal, $2^{\text {nd }}$ ed. (Damascus: Dār al-Fikr, 2007).

Wahbah al-Zuhaylī, al-Fiqh al-Islāmı̄ wa Adillatuh, ed. ke 3 (Damsyik: Dār al-Fikr, 1989).

Yusuf Sani Abubakar, Muhammad Anowar Zahid \& Ruzian Markom, 'Effect of Nomination under Life Insurance and Family Takaful,' ISRA International Journal of Islamic Finance, 6/1 (2014). 
Jurnal Syariah, Jil. 25, Bil. 2 (2017) 247-266

\section{Statut}

Akta Bank Negara Malaysia 2009.

Akta Perkhidmatan Kewangan 2013.

Akta Perkhidmatan Kewangan Islam 2013. 